\title{
Assesstment of Macroeconomic and Financial Performance of Fragile Five and MINT Countries Using TOPSIS Method
}

\author{
Özge Demirkale ${ }^{15}$ \\ Çiğdem Özarı ${ }^{16}$
}

\begin{abstract}
The main purpose of this research is to measure the performance of Fragile Fives and MINT countries (Brazil, India, Indonesia, South Africa, Turkey, Mexico, and Nigeria), based on macroeconomic and financial indicators between 2015-2019. For this purpose, the TOPSIS method, which is one of the multi-criteria models in decision making, was used. In this method, stock market index, exchange rate, inflation and interest rate were decided to use as the main evaluation criteria. According to the findings obtained from the research, Turkey, which is a member of both MINT and the Fragile Five group, was found to be the country with the lowest macroeconomic and financial performance and Indonesia was found to be the best performing country. In addition, this research presents a numerical application to illustrate the use of the TOPSIS method.
\end{abstract}

Key Words: TOPSIS, Macroeconomic and Financial Indicator, Fragile Fives, MINT.

15 Dr. Business Management, İstanbul Aydın University, ozgedemirkale@aydin.edu.tr ORCID: https://orcid.org/0000-0002-4227-3934

16 Dr. Economics and Finance, İstanbul Aydın University, cigdemozari@aydin.edu.tr

ORCID: https://orcid.org/0000-0002-2948-8957

DOI: 10.17932/IAU.FCPE.2015.010/fcpe_v06i2004 


\section{INTRODUCTION}

The formation of a balance in macroeconomic and financial indicators has an important role in ensuring the economic balance of countries. In particular, the instability in the macroeconomic and financial indicators of developing countries is a major difficulty to a balanced economic growth. The common issue of these countries is that they have low per capita income, worthless currency, high interest and inflation rates, savings deficit, and dependence on exports for growth.

Depending on the similarities that developing countries have in terms of macroeconomic indicators, various country groups are formed. Country groups such as the BRICS, MINT (Mexico, Indonesia, Nigeria, and Turkey) and Fragile Fives (Brazil, India, Indonesia, Turkey, and South Africa) are known as groupings within emerging market economies in terms of similarities in their economic and social structures. In 2003, a report for an international investment bank called Goldman Sachs stated that Brazil, China, Russia, and India will have more national income in 2050 than the G- 6 countries and become the leading market economies. With the participation of South Africa, the term BRICS have emerged using the initials of these five countries. The MINT group countries identified by O'neill as the "new quartet" of the world economy at the end of 2013 have emerged. It is stated that these countries will be among the economies of the future for the next 20 years, especially because of their demographic advantages (Hayaloğlu, 2015, 18). The fragile fives classification was first revealed in a report by Morgan Stanley Investment Bank in August 2013. Brazil, India, Indonesia, Turkey, and South Africa were the countries that devalued the most against the US dollar after the FED's decision to start monetary tightening in 2013. Morgan Stanley referred to these countries as "fragile fives" in its August 2013 report (Morgan Stanley, 2013: 1-2).

In Figure 1, the percentage-denominated values of the Fragile Fives and MINT countries ' one-year bond interest rates are presented in the 20152019 period range. Accordingly, Brazil and Nigeria have the highest interest rates between 2015-2016. Between 2017 and 2019, Turkey and Nigeria are among the countries with the highest interest rates. 
Figure 1: Interest Rates of Fragile Fives and MINT countries

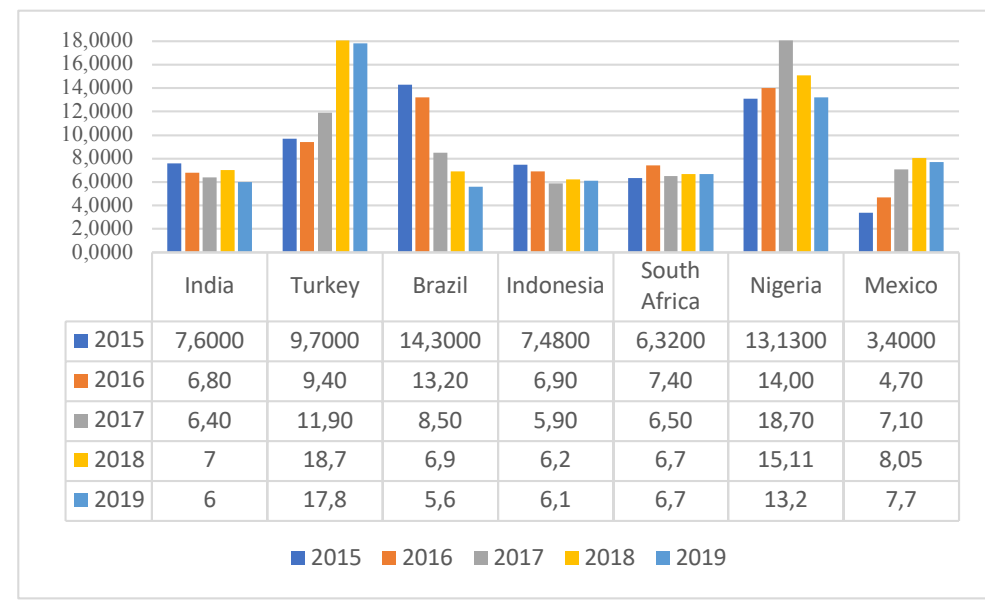

While Turkey, Brazil and Nigeria are among the countries with the highest consumer price index growth rates among the Fragile Fives and MINT countries in the 2015-2016 period range, Brazil has seen an improvement in inflation rates since 2017. Indonesia's inflation rate was $6.3 \%$ in 2015 , a decline of about $3 \%$ in 2019 . India's inflation rate stood at about $4.5 \%$ between 2015-2018, an increase of about $3.12 \%$ in 2019. It is observed that the inflation rates of South Africa and Mexico did not change very much in the respective periods (Figure 2)

Figure 2: Rate of Growth in Consumer Price Index of Fragile Fives and MINT countries

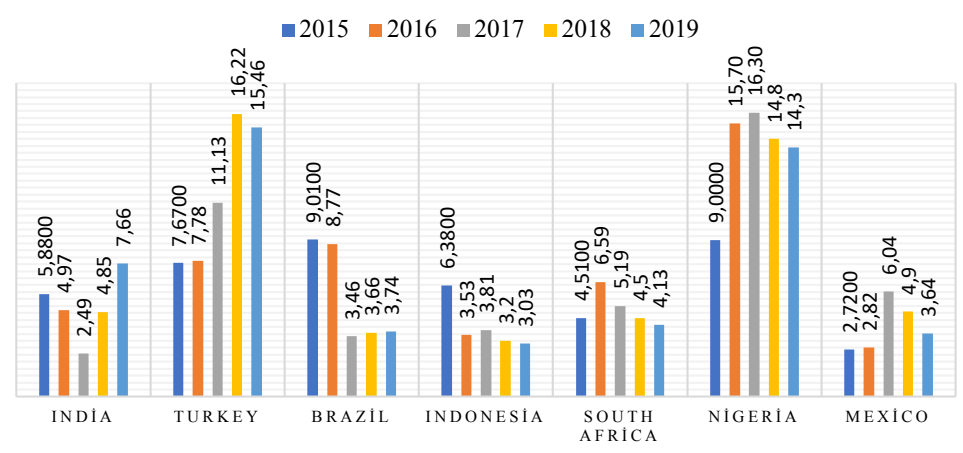


The aim of this research is to compare and rank the macroeconomic and financial performance of 7 countries, which are members of both Fragile Fives and MINT between 2015 and 2019. For this purpose, one of the multi-criteria models in making decision, a Technique for Order Preference by Similarity to an Ideal Solution (TOPSIS) is used as an analysis method. Stock market index, exchange rate, inflation and interest rate were decided to use as the main evaluation criteria to rank these countries based on macroeconomic and financial performance. In this context, studies in the literature using TOPSIS and similar multi-criteria decision making (MCDM) methods were first examined.

\section{LITERATURE REVIEW}

Several methods have been developed in the field of MCDM techniques. These methods have some advantages and/or weaknesses over each other. The decision-maker must decide which of these methods to choose, depending on the character of the problem and the process. The SAW (Simple Additive Weighing) method, developed by Churchman and Ackoff (1954) by applying it to the portfolio selection problem, is one of the most widely used methods in MCDM techniques due to its mathematical simplicity (Yeh, 2003; 291-292).

The ELECTRE (Elimination and Choice Translating Reality English) method, one of the techniques of the MCDM, was first developed by Beneyoun in 1966. This method is based on dual superiority comparisons between alternative decision points for each evaluation Factor (Ersöz ve Kabak, 2010, 111). TOPSIS method, developed by Hwang and Yoon (1981), is a method developed as an alternative to the ELECTRE method. The basis of the TOPSIS method is that the alternative chosen must be at the closest distance to the positive ideal solution while the negative ideal solution must be at the furthest distance (Feng ve Wang, 2000: 138).

The AHP (Analytic Hierarchy Process) method, developed by Thomas L. Saaty in the 1970s, is a powerful and easy-to-understand mathematical method that enables the evaluation of quantitative and qualitative variables in a decision-making process (Dağdeviren ve Eren, 2001: 43). The PROMETHEE (Preference Ranking Organization Method for Enrichment 
Evaluations) method, developed by Brans in 1984, is a method used mostly from locative problems (Zeleny, 1986:17). Multicriteria decision aid methods such as PROMETHEE/GAIA and MAUT allow the decisionmaker to quantify multiple objectives even when these objectives contain conflicting attributes or when they are subjective (Almeida, 2007: 3569).

In the literature, it is possible to find many studies comparing countries in terms of macroeconomic and financial indicators using the TOPSIS method. The TOPSIS method has found a place in the literature especially in recent periods in the field of economics and finance. This section includes some national and international studies conducted in different areas with the methods MCDM.

Özden (2011), ranked the macroeconomic indicators of Turkey with the European Union (EU) countries for the year 2009 using the TOPSIS method. According to the results of the study, the two countries that performed the best were Luxembourg and Denmark, respectively. Turkey was ranked twenty-seventh, while Greece was ranked last.

Ashourian (2012), investigated the Middle East and North Africa (MENA) countries according to the TOPSIS method using socio-economic data from 1997-1999. According to the results of the study, Mauritania as ranked first in 1999, while Turkey was ranked ninth and Lebanon was ranked last.

Genç and Masca (2013), analyzed the macroeconomic performance of EU countries and Turkey for 2012 using TOPSIS and PROMETHEE methods. Economic indicators such as inflation, unemployment rate, long-term interest rates, budget balance, public debt were used as decision criteria. The findings obtained from two analyses were found to be similar. The study also showed that Turkey ranked twenty-first in the PROMETHEE method and eighteenth in the TOPSIS method.

Urfalıoglu and Genç (2013), investigated the macroeconomic indicators of Turkey and EU member and candidate countries for 2010 using TOPSIS, ELECTRE and PROMETHEE methods. In the study using macroeconomic 
indicators such as exports, imports, unemployment, inflation rate, GDP per capita, Turkey was found to be thirteenth in TOPSIS method, thirty-one in ELECTRE method and thirty-second in PROMETHEE method.

Krivka (2014), analyzed the impact of the 2008 crisis on Lithuanian industries between 2006 and 2011 using the methods of SAW, VIKOR and TOPSIS. In the study, pre-economic crisis, crisis order and post-crisis periods were categorized and the industries least and most affected by the crisis were compared by ranking. The study also ranked industries that showed the fastest and slowest recovery after the crisis.

Eyüboğlu (2016), compared the TOPSIS method using macroeconomic indicators of Turkey, Poland, Mexico, Chile, Malaysia, Hungary, Indonesia, China, Argentina and Brazil between 2003 and 2013. According to the results from the study, China and Malaysia were among the best performing countries in the rankings, while Turkey, which was ranked fifth in 2003, was ranked last in 2013.

Balcerzak and Pietrzak (2016), investigated the developments of EU member states in the context of sustainable growth between 2004 and 2013 and the countries considered leaders in this field by the TOPSIS method. The results from the study show that the new EU member states made significant progress in terms of sustainable growth in the period 20042013 and ranked first.

Topçu and Oralhan (2017), examined the macroeconomic indicators of 35 OECD countries between 2010 and 2015 using ELECTRE and TOPSIS methods. According to the results of the TOPSIS method, in which countries are ranked according to their macroeconomic performance, it was determined that Britain was ranked first, Germany was ranked second, and Turkey was ranked thirtieth.

Sevgin and Kundakçı (2017), compared the macroeconomic performance of Turkey and 28 EU countries for 2013 using MOORA and TOPSIS methods. In the study using 6 basic macroeconomic indicators, Turkey 
was ranked among the lowest performing countries compared to the 28 EU countries.

Cihan and Salur (2017), examined the macroeconomic performance of Turkey and BRICS countries between 2004 and 2014 using the TOSIS method. Indicators such as budget deficit/GDP, current balance/GDP, growth, inflation, and unemployment rate were used in the study. The result was that the highest performing country among the BRICS countries was China.

Sevgin and Çağlar (2017), analyzed the sociodemographic and economic variables of the member states of the Organization of Islamic Cooperation (OIC) using Data Envelopment Analysis and the TOPSIS method. According to the results obtained from the TOPSIS method, Turkey was ranked forty-two in the socioeconomic model, thirtieth in the economic model and eighth in the sociodemographic model, while Qatar was ranked first in all three models.

Ela et al. (2018), analyzed the macroeconomic performance of Turkey and EU countries for 2015 using the TOPSIS method. According to the results of the study, Ireland, Cyprus and Poland were among the countries with the best performance, while Turkey, Austria and Belgium were among the countries with the lowest performance.

Künç ve Yaşar (2019), examined the budget revenue-expense and debt variables of Turkey and OECD countries for 2018 using the TOPSIS and VIKOR method. According to the results obtained from the study, the TOPSIS method has been shown to give results that are appropriate according to the expectations of the budget balance performance rankings in the VIKOR method with this method. 
Assesstment of macroeconomic and financial performance of fragile five and mint countries using topsis method

\section{DATA AND TOPSIS METHOD}

Data used in the study, Capital Markets Board, Central Bank of the Republic of Turkey, Investing.com -Stock Market Quotes \& Financial News and Inflation.eu compiled from their website. The countries and stock market index information, exchange rate, interest rate and inflation rate are illustrated in Table 1.

Table 1: Alternatives and Evaluation Criteria of The Research

\begin{tabular}{lcccc}
\hline Target & Max & Min & Min & Min \\
\hline Country & Stock Market & Interest (\%) & Inflation (\%) & Exchange \\
\hline India & BSE Sensex & 1-year bond interest & Consumer Price Index & USD/INR-EUR/INR \\
Turkey & BIST100 & 1-year bond interest & Consumer Price Index & USD/TL- EUR/TL \\
Brazil & BOVESPA & 1-year bond interest & Consumer Price Index & USD/R-EUR/R \\
Indonesia & JSX & 1-year bond interest & Consumer Price Index & USD/IDR-EUR/IDR \\
South Africa & JTOPI & 1-year bond interest & Consumer Price Index & USD/ZAR-EUR/ZAR \\
Nigeria & NSE 30 & 1-year bond interest & Consumer Price Index & USD/NGN-EUR/NGN \\
Mexico & S\&P/BMV IPC (MXX) & 1-year bond interest & Consumer Price Index & USD/MXN-EUR/MXN \\
\hline
\end{tabular}

TOPSIS method was used in the study and this method compared the fragile fives and MINT countries with the data for the period 20152019 in terms of macroeconomic and financial indicators. TOPSIS method, was first put forward by Hwang and Yoon (1981), is a method developed as an alternative to the ELECTRE method. The basis of the TOPSIS method is that the alternative chosen must be at the closest distance to the positive ideal solution while the negative ideal solution must be at the furthest distance (Feng ve Wang, 2000, 138).

In the TOPSIS method, the decision maker defines weights for each criteria and compares the options group by calculating the distance between the positive ideal result and the negative ideal result for each option on these criteria. This method is more effective than other methods because of its features such as easy to use, high consistency, less calculations and programmable (Huang vd., 2011: 17).

TOPSIS method consists of 6 Steps starting with the creation of the decision matrix. The stages of the solution process of the method are as follows (Jahanshahloo, vd., 2006, s. 1378; Özcan vd., 2016b): 
Step 1: Establish a decision matrix for the ranking.

$A=A_{m \times n}=\left[\begin{array}{ccc}a_{11} & \cdots & a_{1 n} \\ \vdots & \ddots & \vdots \\ a_{m 1} & \cdots & a_{m n}\end{array}\right]$

The alternatives which will be ranked are listed in the rows of the decision matrix and the evaluation criteria which will be used for decision making are placed in the columns of the decision matrix. Table 2 illustrates the decision matrix of the research for the year 2015.

Table 2: Decision Matrix (2015)

\begin{tabular}{lcccc}
\hline $\mathbf{2 0 1 5}$ & Stock Market & Exchange & Inflation & Interest \\
\hline India & 27382.9200 & 67.5446 & 5.8800 & 7.6022 \\
Turkey & 79900.9483 & 2.8937 & 7.6700 & 9.7217 \\
Brazil & 49050.0500 & 3.5636 & 9.0100 & 14.3498 \\
Indonesia & 4875.2117 & 14170.9375 & 6.3800 & 7.4816 \\
South Africa & 46262.1183 & 13.5981 & 4.5100 & 6.3292 \\
Nigeria & 1.3983 & 208584.3750 & 9.0000 & 13.1300 \\
Mexico & 43.7710 & 167966.8750 & 2.7200 & 3.4900 \\
\hline
\end{tabular}

The countries which will be ranked have been listed in the rows of the matrix and the evaluation criteria which will be used for decision making are placed in the columns of matrix.

Step 2. Calculate the normalized decision matrix.

The normalized decision matrix is determined using the elements in the decision matrix with the help of the following equality.

$$
r_{i j}=\frac{a_{i j}}{\sqrt{\sum_{i=1}^{m} a_{i j}^{2}}} \mathrm{i}=1,2, \ldots, \mathrm{m} ; \mathrm{j}=1,2, \ldots, \mathrm{n} .
$$

As a result of the calculations made to create the normalized decision matrix. The $\mathrm{R}$ matrix is obtained as follows.

$$
R_{i j}=\left[\begin{array}{ccc}
r_{11} & \cdots & r_{1 n} \\
\vdots & \ddots & \vdots \\
r_{m 1} & \cdots & r_{m n}
\end{array}\right]
$$


In this step, normalized values are multiplied by weight of each indicator. Next, the weighted criterion matrix is formed as shown in Table 3 for the year 2015 .

Table 3: Normalized Decision Matrix (2015)

\begin{tabular}{lcccc}
\hline $\mathbf{2 0 1 5}$ & Stock Market & Exchange & Inflation & Interest \\
\hline India & 0.000002 & 0.000000 & 0.0181 & 0.0119 \\
Turkey & 0.000007 & 0.000000 & 0.0237 & 0.0152 \\
Brazil & 0.000004 & 0.000000 & 0.0278 & 0.0225 \\
Indonesia & 0.000000 & 0.000000 & 0.0197 & 0.0117 \\
South Africa & 0.000004 & 0.000000 & 0.0139 & 0.0099 \\
Nigeria & 0.000000 & 0.000003 & 0.0278 & 0.0206 \\
Mexico & 0.000000 & 0.000002 & 0.0084 & 0.0055 \\
\hline
\end{tabular}

Step 3. Calculate the weighted normalized decision matrix.

To calculate the weighted normalized decision matrix, first the weights of each criteria must be determined by the decision maker. Then the weighted normalized matrix is obtained by multiplying the weight values specified for each criteria.

$$
\sum_{i=1}^{n} w_{i}=1
$$

where $w_{i}$ denotes the weight of $\mathrm{i}^{\text {th }}$ criteria

$$
\mathrm{V}=V_{i j}\left[\begin{array}{ccc}
w_{1} r_{11} & \cdots & w_{n} r_{1 n} \\
\vdots & \ddots & \vdots \\
w_{1} r_{m 1} & \cdots & w_{n} r_{m n}
\end{array}\right]
$$

Table 4: Weighted Normalized Decision Matrix (2015)

\begin{tabular}{lcccc}
\hline $\mathbf{2 0 1 5}$ & Stock Market & Exchange & Inflation & Interest \\
\hline India & 0.000000 & 0.000000 & 0.0018 & 0.0012 \\
Turkey & 0.000001 & 0.000000 & 0.0024 & 0.0015 \\
Brazil & 0.000000 & 0.000000 & 0.0028 & 0.0022 \\
Indonesia & 0.000000 & 0.000000 & 0.0020 & 0.0012 \\
South Africa & 0.000000 & 0.000000 & 0.0014 & 0.0010 \\
Nigeria & 0.000000 & 0.000000 & 0.0028 & 0.0021 \\
Mexico & 0.000000 & 0.000000 & 0.0008 & 0.0005 \\
\hline
\end{tabular}


Step 4. Determine the positive-ideal and negative-ideal solutions.

$\mathrm{J}$ for the profit index and $J^{\prime}$ for the cost index

Positive Ideal: $A^{*}=\left\{\left(\max _{i} v_{i j} \mid j \in J\right),\left(\min _{i} v_{i j} \mid j \in J^{\prime}\right\}\right.$ and $A^{*}=\left\{v_{1}^{*}, v_{2}^{*}, \ldots, v_{n}^{*}\right\}$

Negative Ideal: $A^{-}=\left\{\left(\min _{i} v_{i j} \mid j \in J\right),\left(\max _{i} v_{i j} \mid j \in J^{\prime}\right\}\right.$ and $A^{-}=\left\{v_{1}^{-}, v_{2}^{-}, \ldots, v_{n}^{-}\right\}$

Step 5. Calculating the distances of the positive and negative ideal solution points of each alternative.

$$
S_{i}^{+}=\sqrt{\sum_{j=1}^{n}\left(v_{i j}-v_{j}^{*}\right)^{2}} i=1.2 \ldots . m \text { and } S_{i}^{-}=\sqrt{\sum_{j=1}^{n}\left(v_{i j}-v_{j}^{-}\right)^{2}} i=1.2 \ldots . m
$$

Table 5: Positive Ideal Solution

\begin{tabular}{lccccc}
\hline $\mathbf{2 0 1 5}$ & Stock Market & Exchange & Inflation & Interest & $\boldsymbol{S}_{\boldsymbol{i}}^{+}$ \\
\hline India & 0.000000 & 0.000000 & 0.000001 & 0.000000 & 0.001168515 \\
Turkey & 0.000000 & 0.000000 & 0.000002 & 0.000001 & 0.001812538 \\
Brazil & 0.000000 & 0.000000 & 0.000004 & 0.000003 & 0.002580326 \\
Indonesia & 0.000000 & 0.000000 & 0.000001 & 0.000000 & 0.00129084 \\
South Africa & 0.000000 & 0.000000 & 0.000000 & 0.000000 & 0.000709009 \\
Nigeria & 0.000000 & 0.000000 & 0.000004 & 0.000002 & 0.002456299 \\
Mexico & 0.000000 & 0.000000 & 0.000000 & 0.000000 & $7.21176 \mathrm{E}-07$ \\
\hline
\end{tabular}

Table 6: Negative Ideal Solution

\begin{tabular}{lccccc}
\hline $\mathbf{2 0 1 5}$ & Stock Market & Exchange & Inflation & Interest & $\boldsymbol{S}_{\boldsymbol{i}}^{-}$ \\
\hline India & 0.000000 & 0.000000 & 0.000001 & 0.000001 & 0.001431346 \\
Turkey & 0.000000 & 0.000000 & 0.000000 & 0.000001 & 0.000834188 \\
Brazil & 0.000000 & 0.000000 & 0.000000 & 0.000000 & $5.09644 \mathrm{E}-07$ \\
Indonesia & 0.000000 & 0.000000 & 0.000001 & 0.000001 & 0.001347099 \\
South Africa & 0.000000 & 0.000000 & 0.000002 & 0.000002 & 0.001872169 \\
Nigeria & 0.000000 & 0.000000 & 0.000000 & 0.000000 & 0.00019096 \\
Mexico & 0.000000 & 0.000000 & 0.000004 & 0.000003 & 0.002580326 \\
\hline
\end{tabular}

Step 5. Calculate the relative closeness to the ideal solution and rank the alternatives.

$\mathrm{C}_{\mathrm{i}}^{*}=\frac{\mathrm{S}_{\mathrm{i}}^{-}}{\mathrm{S}_{\mathrm{i}}^{-}+\mathrm{S}_{\mathrm{i}}^{+}} \mathrm{i}=1,2, \ldots, \mathrm{m}$. 
Assesstment of macroeconomic and financial performance of fragile five and mint countries using topsis method

Table 7: Distances from Positive Ideal and Negative Ideal Solutions and Relative Closeness to The Ideal Solution (2015)

\begin{tabular}{lccc}
\hline $\mathbf{2 0 1 5}$ & $\boldsymbol{S}_{\boldsymbol{i}}^{+}$ & $\boldsymbol{S}_{\boldsymbol{i}}^{-}$ & $\boldsymbol{C}_{\boldsymbol{i}}$ \\
\hline India & 0.0012 & 0.0014 & 0.5505 \\
Turkey & 0.0018 & 0.0008 & 0.3152 \\
Brazil & 0.0026 & 0.0000 & 0.0002 \\
Indonesia & 0.0013 & 0.0013 & 0.5107 \\
South Africa & 0.0007 & 0.0019 & 0.7253 \\
Nigeria & 0.0025 & 0.0002 & 0.0721 \\
Mexico & 0.0000 & 0.0026 & 0.9997 \\
\hline
\end{tabular}

The ranking by the TOPSIS method shows that the country with the best performance in terms of macroeconomic and financial indicators in 2015 is Mexico. The second and third place are South Africa and India, respectively. Brazil, on the other hand, is seen as the country with the worst performance among the Fragile Fives and MINT countries in 2015, taking seventh place.

Figure 3: 2015 Ranking Results

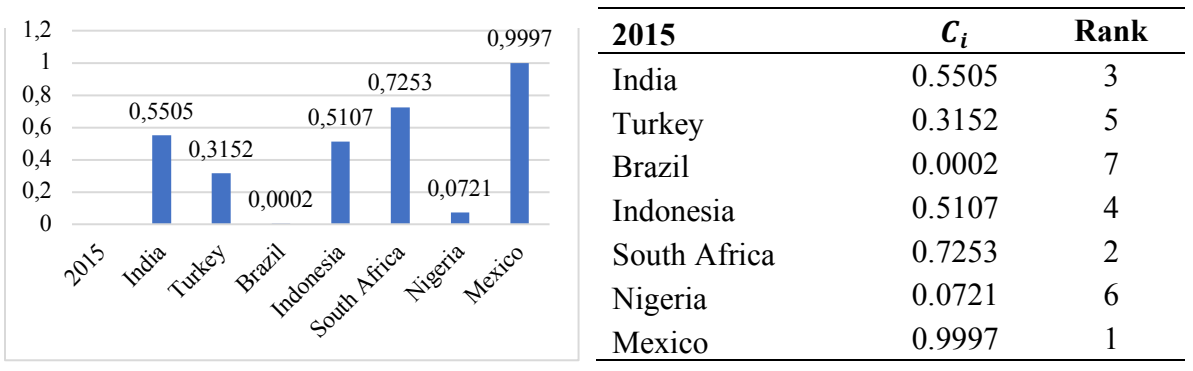

The ranking by the TOPSIS method shows that the country with the best performance in terms of macroeconomic and financial indicators in 2016 is Mexico. Brazil was ranked sixth, up one place from the previous year. Turkey has drawn a similar picture between 2015 and 2016. 
Figure 4: 2016 Ranking Results

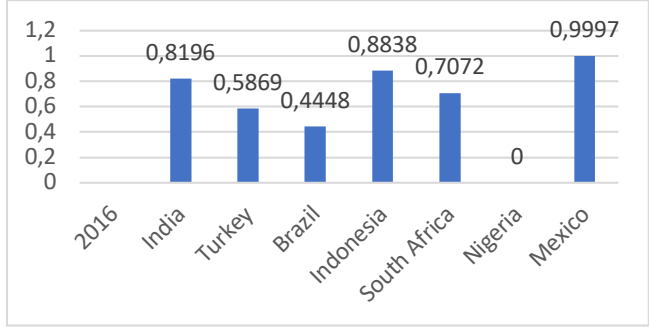

\begin{tabular}{lcc}
\hline $\mathbf{2 0 1 6}$ & $\boldsymbol{C}_{\boldsymbol{i}}$ & Rank \\
\hline India & 0.8196 & 3 \\
Turkey & 0.5869 & 5 \\
Brazil & 0.4448 & 6 \\
Indonesia & 0.8838 & 2 \\
South Africa & 0.7072 & 4 \\
Nigeria & 0.0000 & 7 \\
Mexico & 0.9997 & 1 \\
\hline
\end{tabular}

In 2017, Mexico declined to fifth place. India is in the first place and Indonesia is in second place. It has been observed that Turkey has declined in a row compared to previous years.

Figure 5: 2017 Ranking Results

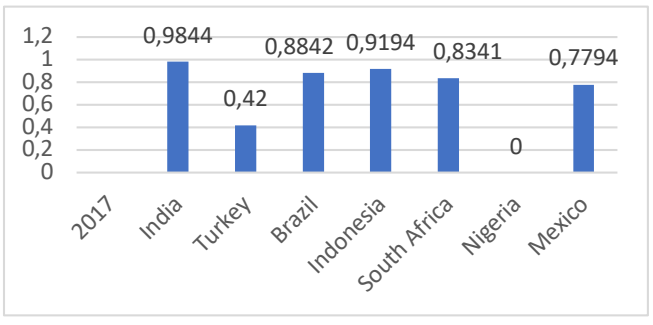

\begin{tabular}{lcc}
\hline $\mathbf{2 0 1 7}$ & $\boldsymbol{C}_{\boldsymbol{i}}$ & Ran \\
\hline India & 0.9844 & 1 \\
Turkey & 0.4200 & 6 \\
Brazil & 0.8842 & 3 \\
Indonesia & 0.9194 & 2 \\
South Africa & 0.8341 & 4 \\
Nigeria & 0.0000 & 7 \\
Mexico & 0.7794 & 5 \\
\hline
\end{tabular}

In 2018, Mexico preserved its place in the rankings compared to the previous year. India has regressed in the rankings and placed fourth. Turkey and Nigeria's rankings changed places compared to the previous year and they were ranked seventh and sixth, respectively.

Figure 6: 2018 Ranking Results

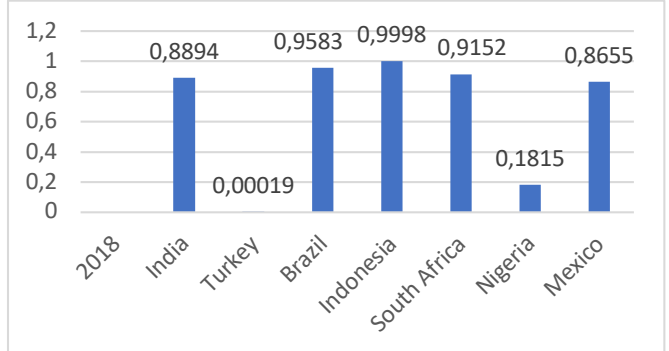

\begin{tabular}{lcc}
\hline \multicolumn{1}{c}{$\mathbf{2 0 1 8}$} & $\boldsymbol{C}_{\boldsymbol{i}}$ & Rank \\
\hline India & 0.8894 & 4 \\
Turkey & 0.0000 & 7 \\
Brazil & 0.9583 & 2 \\
Indonesia & 0.9998 & 1 \\
South Africa & 0.9152 & 3 \\
Nigeria & 0.1815 & 6 \\
Mexico & 0.8655 & 5 \\
\hline
\end{tabular}


Assesstment of macroeconomic and financial performance of fragile five and mint countries using topsis method

In 2019, it was determined that the rankings of Mexico, Turkey and Nigeria remained the same compared to the previous year. Indonesia is ranked first in 2018 as well as in 2019.

Figure 7: 2019 Ranking Results

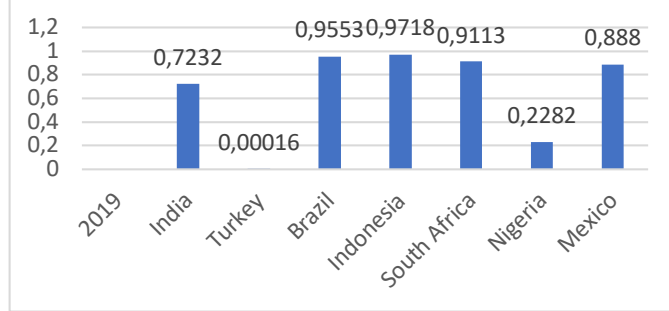

\begin{tabular}{lcc}
\hline $\mathbf{2 0 1 9}$ & $\boldsymbol{C}_{\boldsymbol{i}}$ & Rank \\
\hline India & 0.7232 & 4 \\
Turkey & 0.0002 & 7 \\
Brazil & 0.9553 & 2 \\
Indonesia & 0.9718 & 1 \\
South & 0.9113 & 3 \\
Africa & 0.2282 & 6 \\
Nigeria & 0.8880 & 5 \\
Mexico &
\end{tabular}

\section{FINDINGS}

In this section, the results of the analysis were evaluated. Stock market index, exchange rate, inflation and interest rate data for the period 2015-2019 were used as macro-economic and financial indicators of the countries. The proximity value $\left(C_{i}\right)$ and the ranking of countries obtained from positive ideal solutions consisting of the best performance values and negative ideal solutions consisting of the worst performance values are given in Table 8 by the TOPSIS method. The highest value of $C_{i}$ indicates the alterative (country) for which it is best in terms of the 4 criteria determined. If this value is the lowest value, it indicates the alternative (country) where the performance is worst in terms of the criteria in question.

Table 8: Ranking Results (2015-2019)

\begin{tabular}{|c|c|c|c|c|c|c|c|c|c|}
\hline \multirow[b]{2}{*}{ India } & \multicolumn{2}{|c|}{$C_{i} \&$ Rank } & \multicolumn{2}{|c|}{$C_{i} \&$ Rank } & \multicolumn{2}{|c|}{$C_{i} \&$ Rank } & \multicolumn{2}{|c|}{$C_{i} \&$ Rank } & \multirow{2}{*}{$\frac{\boldsymbol{C}_{\boldsymbol{i}} \text { \& Rank }}{0.72}$} \\
\hline & 0.55 & 3 & 0.82 & 3 & 0.98 & 1 & 0.89 & 4 & \\
\hline Turkey & 0.32 & 5 & 0.59 & 5 & 0.42 & 6 & 0.00 & 7 & 0.00 \\
\hline Brazil & 0.00 & 7 & 0.44 & 6 & 0.88 & 3 & 0.96 & 2 & 0.96 \\
\hline Indonesia & 0.51 & 4 & 0.88 & 2 & 0.92 & 2 & 1.00 & 1 & 0.97 \\
\hline South Africa & 0.73 & 2 & 0.71 & 4 & 0.83 & 4 & 0.92 & 3 & 0.91 \\
\hline Nigeria & 0.07 & 6 & 0.00 & 7 & 0.00 & 7 & 0.18 & 6 & 0.23 \\
\hline Mexico & 1.00 & 1 & 1.00 & 1 & 0.78 & 5 & 0.87 & 5 & 0.89 \\
\hline
\end{tabular}


As seen from Figure 8, the ranking by the TOPSIS method has been observed to place Nigeria sixth and/or seventh in the period 2015-2019. Nigeria was ranked sixth in 2015, its place in the rankings declined in 2016 and 2017 and has continued to be ranked sixth again in the past two years. In 2015 and 2016, Turkey was ranked fifth, while its place in the rankings declined from 2017-2019, and it was found to be ranked seventh in 2019. In this context, between 2015 and 2019, Turkey and Nigeria had similar performance levels in terms of macroeconomic and financial indicators.

Another conclusion noted in the study is that Brazil's performance improved according to its macroeconomic and financial indicators between 2015-2019. Brazil was ranked seventh in 2015 and sixth in 2016, while it experienced an improvement in its macro-economic and financial indicators between 2017 and 2019, placing second in 2019. Mexico, on the other hand, is showing the opposite picture with Brazil. Mexico was ranked first from 2015-2016, while it is seen to have dropped to fifth from 2017-2019

With the exception of 2017, India and South Africa have similarperformance levels, according to the rankings made by the TOPSIS method. Another conclusion from the study is that Indonesia had a stable performance in terms of macroeconomic and financial indicators between 2015-2019.

Figure 8: Ranking of Countries in terms of Their Macroeconomic and Financial Performance (2015-2019)

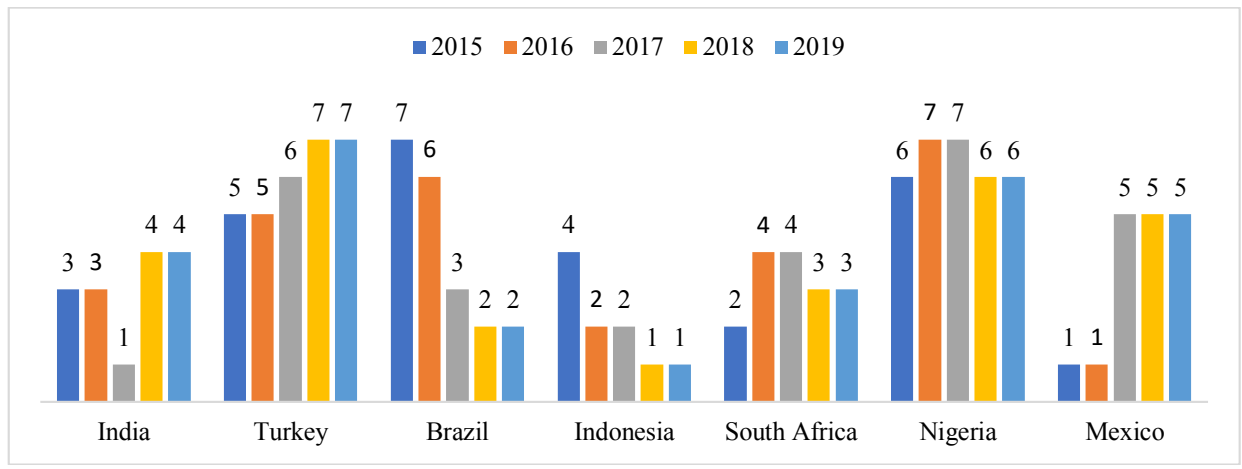




\section{CONCLUSION}

In this study, the macroeconomic and financial performance of Fragile Five and MINT countries were measured according to the selected criteria using the TOPSIS method, which is one of the multi-criteria decisionmaking methods. The study covers the years 2015-2019. The criteria used in the study consist of stock market index, exchange rate, inflation, and interest rate data.

In the rankings made by the TOPSIS method, Nigeria was ranked sixth in 2015, its place in the rankings declined in 2016 and 2017, and it has continued to be ranked sixth again in the past two years. In 2015 and 2016, Turkey was ranked fifth, while its place in the rankings declined from 2017-2019, and it was found to be ranked seventh in 2019. In this context, between 2015 and 2019, Turkey and Nigeria had similar performance levels in terms of macroeconomic and financial indicators.

Another notable result in the study is that Brazil's performance improved relative to its macro-economic and financial indicators between 20152019. Brazil, which finished seventh in 2015 , was found to have moved up to second place in 2019. Mexico was ranked first from 2015-2016, while it declines to fifth from 2017-2019. Another result from the study showed that Indonesia had a stable performance in terms of macroeconomic and financial indicators between 2015-2019. It has also been found that India, which came in first place in 2017, has declined to fourth place in 2019.

When we rank countries according to their macroeconomic and financial performance for 2019, the best performing country appears to be Indonesia. Brazil and South Africa were placed second and third, respectively. The countries with the worst performance in terms of macroeconomic and financial indicators are Turkey, Nigeria and Mexico, respectively. The worst performance ranking in the study was found to show similarity as of 2017.

Country groups such as Fragile Five and MINT countries are known as groupings within emerging market economies in terms of similarities in their economic and social structures. Morgan Stanley's August 2013 report 
found that Brazil, India, Indonesia, Turkey and South Africa were among the most depreciating countries against the US dollar following the Fed's decision to start monetary tightening. According to the findings from the study, Turkey, which is part of the Fragile Five group, was found to be the country with the most weakness. Indonesia, which is part of the MINT and Fragile Five group, was found to be the best performing country.

Although the study has significant contributions, it is not possible to sustain the study without constraints. But it is thought that these constraints will be an opportunity for further research. One limitation is that the study was conducted between 2015-2019. It is thought that expanding the analysis period by participating especially in crisis periods, as well as measuring the performance of countries by including different criteria into the analysis will make important contributions to the literature of decision analysis and techniques.

In this research, each of the 4 criteria has $1 / 4$ weight. Further researches can be made by elimination of these limitations. It is also possible to use other MCDM methods such as ELECTRE, AHP, PROMETHEE, VIKOR etc. 
Assesstment of macroeconomic and financial performance of fragile five and mint countries using topsis method

\section{ATTACHMENT}

Table 1: Decision Matrix (2016)

\begin{tabular}{lcccc}
\hline $\mathbf{2 0 1 6}$ & Stock Market & Exchange & Inflation & Interest \\
\hline India & 26505.69 & 70.72 & 4.97 & 6.82 \\
Turkey & 77392.32 & 3.18 & 7.78 & 9.45 \\
Brazil & 53983.23 & 3.63 & 8.77 & 13.24 \\
Indonesia & 5059.89 & 14018.85 & 3.53 & 6.90 \\
South Africa & 45303.62 & 15.32 & 6.59 & 7.48 \\
Nigeria & 1.18 & 273722.92 & 15.70 & 14.00 \\
Mexico & 45.90 & 196699.67 & 2.82 & 4.77 \\
\hline
\end{tabular}

Table 2: Decision Matrix (2017

\begin{tabular}{lcccc}
\hline $\mathbf{2 0 1 7}$ & Stock Market & Exchange & Inflation & Interest \\
\hline India & 31162.84 & 63.57 & 2.49 & 6.37 \\
Turkey & 100439.03 & 3.89 & 11.13 & 11.90 \\
Brazil & 68421.86 & 3.42 & 3.46 & 8.46 \\
Indonesia & 5785.12 & 14333.30 & 3.81 & 5.99 \\
South Africa & 48457.88 & 14.22 & 5.19 & 6.57 \\
Nigeria & 1.45 & 328407.79 & 16.30 & 18.74 \\
Mexico & 49.00 & 201871.08 & 6.04 & 7.11 \\
\hline
\end{tabular}

Table 3: Decision Matrix (2018)

\begin{tabular}{lcccc}
\hline $\mathbf{2 0 1 8}$ & Stock Market & Exchange & Inflation & Interest \\
\hline India & 35683.95 & 74.50273 & 4.85 & 7.046167 \\
Turkey & 101782.1 & 5.276929 & 16.22 & 18.77667 \\
Brazil & 82609.89 & 4.005104 & 3.66 & 6.92875 \\
Indonesia & 6098.583 & 15510.26 & 3.2 & 6.262833 \\
South Africa & 49694.68 & 14.46143 & 4.5 & 6.696667 \\
Nigeria & 1.679318 & 335840.6 & 14.8 & 15.11 \\
Mexico & 46.73069 & 209548.6 & 4.9 & 8.05 \\
\hline
\end{tabular}

Table 4: Decision Matrix (2019)

\begin{tabular}{lcccc}
\hline $\mathbf{2 0 1 8}$ & Stock Market & Exchange & Inflation & Interest \\
\hline India & 38716.27 & 74.49827 & 7.66 & 6.044583 \\
Turkey & 100709.2 & 6.011408 & 15.46 & 17.86917 \\
Brazil & 101794.5 & 4.182117 & 3.74 & 5.6 \\
Indonesia & 6324.663 & 14944.56 & 3.03 & 6.170583 \\
South Africa & 50080.64 & 15.2834 & 4.13 & 6.692083 \\
Nigeria & 1.232455 & 355706.3 & 14.3 & 13.29 \\
Mexico & 43.06634 & 204957.5 & 3.64 & 7.75 \\
\hline
\end{tabular}




\section{REFERENCES}

[1] Ashourian. M. (2012). Evaluating the Rank of Performance of Countries of the Middle East and North Africa with MADM. Journal of Informatics and Mathematical Sciences. Vol. 4. No. 3. 285-292.

[2] Balcerzak A.P. \& Pietrzak. M.B. (2016). Application of TOPSIS Method for Analysis of Sustainable Development in European Union Countries. The 10th International Days of Statistics and Economics. Prague. September 8(10). 82-92.

[3] Cihan. Y. \& Salur. M. N. (2017). Comparison of the Economic Performance between Turkey and Brics Countries Using TOPSIS Method. Journal of Current Research on Business and Economics. 7(2). 350-358.

[4] Dağdeviren, M., Eren, T. (2001). Tedarikçi Firma Seçiminde Analitik Hiyerarşi Prosesi ve 0-1 Hedef Programlama Yöntemlerinin Kullanılması. Gazi Üniversitesi Mühendislik-Mimarlık Fakültesi Dergisi, Cilt: 16, No. 2, 41-52.

[5] De Almeida, A. T. (2007). Multicriteria decision model for outsourcing contracts selection based on utility function and ELECTRE method. Computers \& operations research, 34(12), 3569-3574.

[6] Ela. M.. Doğan. A. and Uçar. O. (2018). Comparıson of EU Countrıes and Turkey's Macroeconomic Performannces with TOPSIS Method. Osmaniye Korkut Ata University Journal of Economics and Administrative Sciences Vol: 2. Issue: 2. December 2018. pp. 129-143.

[7] Ersöz, F. \& Kabak, M. (2010). "Savunma Sanayi Uygulamalarında Çok Kriterli Karar Verme Yöntemlerinin Literatür Araştırması”, Savunma Bilimleri Dergisi, Cilt 9, Sayı 1: 97-125. 
[8] Eyüboğlu. K. (2016). Comparison of Developing Countries’ Macro Performances with AHP and TOPSIS Methods. Cankırı Karatekin University Journal of the Faculty of Economics and Administrative Sciences. 6(1). 131-146.

[9] Feng, C. M \& Wang, R. T. (2000). "Performance Evaluation for Airlines Including the Consideration of Financial Ratios", Journal of Air Transport Management, 6: 133-142.

[10] Genç. T. ve Masca. M. (2013). The Comparıson of the Outrankıng Results of TOPSIS and Promethee Methods.KOCATEPE IIBF Journal of İİB Dergisi. 15(2). 539-567.

[11] Hayaloğlu, P. (2015). How Democracy Effects Economic Growth in MINT Countries? International Journal of Economics and Innovation, $1(1), 17-29$.

[12] Huang. I. \& Keisler B. J. \& Linkov I. (2011). Multi-criteria Decision Analysis in Environmental Sciences: Ten Years of Applications and Trends. Science of the Total Environment. 409(19). 3578-3594.

[13] Jahanshahloo. G. R.. Lotfi. F. H.. Izadikhah. M. (2006). An Algorithmic Method to Extend TOPSIS for Decision-Making Problems with Interval Data. Applied Mathematics and Computation. 175 (2). 1375-1384.

[14] Krivka. A. (2014). Complex Evaluation of the Economic Crisis Impact on Lithuanian Industries. Journal of Business Economics and Management. 15(2). 299-315.

[15] Künç. G.Y. \& Yaşa. A.A. (2019). Comparion of the Budget Indicators of Turkey and OECD Countries with TOPSIS and VIKOR Methods. BEÜ SBE Journal. 8(2). 366-384. 
[16] Özcan U.. Doğan A.. Söylemez İ. (2016b). Evaluation Of Research Projects Of Undergraduate Students İn An Engineering Department Using TOPSIS Method. The Eurasia Proceedings of Educational \& Social Sciences (EPESS). 5(1). 420-424.

[17] Özden, Ü. H. (2011). Topsis Method With The European Union Member States Of The Candidate And Mapping Of Economic Indicators. Trakya University Journal of Social Science .13(2), 215-236.

[18] Sevgin H. \& Çağlar A.(2017). Comparison of the Islamic Conference Member Countries via Data Envelopment Analysis and TOPSIS Method. Ordu University Journal of Social Science Research. 7(2). 221-244. July. 2017.

[19] Sevgin. H.\&Kundakç1. N. (2017). Ranking of European Union Member Countries and Turkey According to the Economic Indicators with TOPSIS and MOORA Methods. Anadolu University Journal of Social Sciences. 17(3). 87-107.

[20] Stanley, M. (2013). Global EM Investor Fragile Five, http://graphics8. nytimes.com/packages/p df/business/MorganStanleyFragileFive.pdf. Erişim Tarihi: 12.11.2019.

[21] Topçu, A.B.\& Oralhan. B. (2017). The Comparison of Turkey and Other OECD Countries with Multi Criteria Decision Making Methods in Terms of Basic Macroeconomic Indicators. International Journal of Academic Value Studies. 3(14). 260-277.

[22] Urfalığlu. F. \& Genç. T. (2013). Comparison Of The Economic Performance Between Turkey And The European Union Members With Multi Criteria Decision Making Methods. Marmara University Journal of İ.İ.B. XXXV(II). 329-359. 
Assesstment of macroeconomic and financial performance of fragile five and mint countries using topsis method

[23] Yeh, C.H. (2003). “The Selection Of Multiattribute Decision Making Methods For Scholarship Student Selection", International Journal of Selection and Assessment, 11(4): 289-296.

[24] Zeleny, M., Multiple Criteria Decision Making, Mc-Graw-Hill, New York, 13-47, 1986. 